Alfian Chrisna Aji, Mohammad Masykuri, Retno Rosariastuti. (2019). Fitoremediasi Logam Kromium di Tanah sawah dengan Rami (Boehmeria Nivea) dan Environmental Health Agriclture System (EHAS). Journal Bioeksperimen. Vol. 5 (2) Pp. 61-69. Doi: 10.23917/bioeksperimen.v5i2.2795

\title{
FITOREMEDIASI LOGAM KROMIUM DI TANAH SAWAH DENGAN RAMI (BOEHMERIA NIVEA) DAN ENVIRONMENTAL HEALTH AGRICULTURE SYSTEM (EHAS)
}

\author{
Alfian Chrisna Aji ${ }^{*}$, Mohammad Masykuri², Retno Rosariastuti ${ }^{3}$ \\ ${ }^{1}$ Pascasarjana Ilmu Lingkungan, Universitas Sebelas Maret \\ ${ }^{2}$ Fakultas Keguruan dan Ilmu Pendidikan, Universitas Sebelas Maret \\ ${ }^{3}$ Fakultas Pertanian, Universitas Sebelas Maret \\ *E-mail: alvian0907@gmail.com
}

Paper diterima : 19 Juni 2017, Paper publish : September 2019

\begin{abstract}
Chromium metal is one of the heavy metal wastes from various industries and is persistent for the agricultural environment, especially in rice fields. Chromium metal can change biodiversity and ecosystem function in paddy soil. Chromium metal phytoremediation that pollutes paddy soils with hemp (Boehmeria nivea) is important because paddy soils play a role as a living medium for food crops, especially rice (Oryza sativa). One indicator of the success of phytoremediation is the reduction of chromium metal content in the soil, so it requires a policy system to maintain a healthy environmentally friendly agriculture. This study aimed to determine the ability of Boehmeria nivea to reduce levels of chromium metal in the soil and provide policy solutions to keep environmentally healthy agriculture. This study used a complete randomized block design, random sampling of chromium metal data. The results showed the initial concentration of chromium metal in the soil was 2.36 ppm, after treatment with the interaction between Agrobacterium sp. I3 with Boehmeria nivea (P0B1T1) and interaction of organic matter (compost) with Boehmeria nivea (POB2T1) obtained Cr 1.37 ppm metal content with a decrease of $42.01 \%$. The resulting policy solution is the Environment Health Agriculture System (EHAS). The conclusion of this study was phytoremediation of chromium metal using Boehmeria nivea combined with the Environment Health Agriculture System can create a healthy environmentally friendly agricultural system.
\end{abstract}

Keywords: Boehmeria nivea, Environment Health Agriculture System, phytoremediation, chromium.

\section{Pendahuluan}

Laju pembangunan semakin pesat, terutama di bidang ilmu pengetahuan dan teknologi (IPTEK) yang memungkinkan manusia memanfaatkan sumber daya alam (SDA) untuk memenuhi kebutuhan. Pemanfaatan SDA untuk kegiatan pembangunan disertai dengan pencemaran (Budiastuti, 2010, Dogo et al., 2011). Salah satu pencemaran adalah limbah yang dihasilkan oleh industri. Limbah yang dihasilkan berupa logam berat, salah satunya adalah logam kromium (Cr) yang bersifat persisten bagi lingkungan (Pramono, 2012).

Logam $\mathrm{Cr}$ adalah salah satu logam berat yang digunakan sebagai bahan baku kegiatan industri, seperti penyamakan kulit, pembakaran minyak dan batu bara, pewarnaan tekstil, pelapisan logam, dan pembuatan baja tahan terhadap korosi (Han et al., 2004; Owlad et al., 2009; Rosariastuti et al., 2013).

Logam $\mathrm{Cr}$ di dalam lingkungan ditemukan pada bentuk ion $\mathrm{Cr}$ (III) dan ion Cr(IV) (Banks et al., 2006). Ion $\mathrm{Cr}$ (III) mempunyai toksisitas yang lebih rendah daripada ion $\mathrm{Cr}(\mathrm{VI})$, relatif kurang berbahaya, dan dalam jumlah seimbang membantu metabolisme gula pada manusia (Khan et al., 2009). Tetapi, kadar ion Cr(III) yang berlebihan dapat merusak materi genetik (Eastmond et al., 2008). Sedangkan, ion Cr(VI) bersifat mudah larut, teratogenik, mutagenik, karsinogenik, klorosis pada tanaman, dan toksisitas tinggi yang dapat mengakibatkan kematian mikroorganisme, hewan, dan manusia 
(Shanker et al., 2005; Dong et al., 2007; Han et al., 2010).

Logam Cr yang masuk dibuang ke perairan dan menjadi sumber irigasi pertanian dapat mencemari tanah sawah apabila melebihi nilai ambang batas yang ditetapkan. Nilai ambang batas logam $\mathrm{Cr}$ pada tanah, terutama ion $\mathrm{Cr}(\mathrm{VI})$ menurut Peraturan Pemerintah Republik Indonesia No. 101 Tahun 2014 tentang Pengelolaan Limbah Bahan Berbahaya dan Beracun adalah 2,5 mg. $\mathrm{kg}^{-1}$.

Undang-Undang Republik Indonesia Nomor 32 Tahun 2009 tentang Perlindungan dan Pengelolaan Lingkungan hidup mewajibkan program pemeliharaan lingkungan untuk menganggulangi pencemaran logam Cr. Pencemaran $\mathrm{Cr}$ di tanah sawah dapat ditanggulangi dengan penerapan teknologi modern yang aman, murah, serta ramah lingkungan, yaitu fitoremediasi (Susarla et al., 2002). Fitoremediasi adalah suatu teknologi perbaikan kualitas lingkungan dengan memanfaatkan tanaman yang aman, murah, dan ramah lingkungan (Ghosh dan Singh, 2005; Glick, 2010; Aji et al., 2017). Indikator keberhasilan fitoremediasi, salah satunya dilihat dari penurunan kadar logam dalam tanah.

Boehmerianiveamemilikisifatpertumbuhan cepat, menghasilkan biomassa besar, dan serat yang digunakan sebagai bahan dasar kerajinan anyaman, campuran tekstil, dan pulp berkualitas tinggi sebagai bahan baku pembuatan kertas (Purwati, 2010). Upaya untuk memaksimalkan potensi $B$. nivea adalah dengan penambahan agen khelator untuk meningkatkan kemampuan bertahan hidup tanaman dari toksisitas logam, meningkatkan penyerapan, pengangkutan, dan akumulasi logam ke tajuk (Do Nascimento dan Xing, 2006).
Agen khelator yang diberikan adalah Agrobacteriumsp. I dan bahan organik(kompos). Agrobacterium sp. I 3 mampu meningkatkan penyerapan dan pengakumulasian logam $\mathrm{Cr}$ ke akar dan tajuk $B$. nivea sehingga dapat menurunkan kadar logam $\mathrm{Cr}$ pada tanah terkontaminasi (Rosariastuti et al., 2013). Sedangkan, bahan organik berpengaruh terhadap perbaikan tanah, baik dari faktor fisika, kimia, maupun biologi tanah (Suntoro, 2010).

Penerapan fitoremediasi dengan $B$. nivea yang dibantu agen khelator pada sawah tercemar logam $\mathrm{Cr}$ diharapkan dapat menciptakan pertanian yang sehat ramah lingkungan. Kunci terciptanya pertanian yang sehat ramah lingkungan adalah tersedianya tanah yang sehat (subur dan produktif), yaitu tanah yang mampu menyokong pertumbuhan tanaman serta bebas dari berbagai bahan pencemar (Suntoro, 2010). Penelitian ini bertujuan mengetahui kemampuan Boehmeria nivea untuk menurunkan kadar logam kromium dalam tanah dan memberikan solusi kebijakan untuk menjaga pertanian sehat ramah lingkungan.

\section{Metode Penelitian}

\section{Pengumpulan Sampel}

Sampel dikumpulkan pada bulan Juni sampai Juli 2016 dari petak sawah yang berukuran $\pm 100 \mathrm{~m}^{2}$ di Desa Waru, Kebakkramat, Karanganyar, Jawa Tengah (7³0'36,4” LS - 11054’21,4” BT, $\pm 108 \mathrm{~m}$ di atas permukaan air laut). Pengambilan data kadar logam $\mathrm{Cr}$ tanah dilakukan secara random sampling. Rancangan penelitian menggunakan rancangan acak kelompok lengkap dengan jenis percobaan faktorial desain (Tabel 1). 
Tabel 1. Rancangan Penelitian

\begin{tabular}{|c|c|c|c|c|c|}
\hline \multicolumn{3}{|c|}{ Perlakuan } & \multirow{2}{*}{\multicolumn{3}{|c|}{$\begin{array}{c}\text { Kombinasi Perlakuan } \\
\text { Ulangan }(\mathrm{U})\end{array}$}} \\
\hline \multirow{2}{*}{$\begin{array}{l}\text { Pupuk Dasar } \\
\text { (P) }\end{array}$} & \multirow{2}{*}{$\begin{array}{l}\text { Agen Khelator } \\
\text { (B) }\end{array}$} & \multirow{2}{*}{$\begin{array}{c}\text { Tanaman } \\
\text { Akumulator }(\mathrm{T})\end{array}$} & & & \\
\hline & & & 1 & 2 & 3 \\
\hline \multirow[t]{7}{*}{ P0 } & B0 & T0 & P0B0T0 & Р0B0T0 & Р0B0T0 \\
\hline & & $\mathrm{T} 1$ & P0B0T1 & P0B0T1 & P0B0T1 \\
\hline & B1 & T0 & P0B1T0 & P0B1T0 & P0B1T0 \\
\hline & & $\mathrm{T} 1$ & P0B1T1 & P0B1T1 & P0B1T1 \\
\hline & B2 & T0 & Р0B2T0 & Р0B2T0 & Р0B2T0 \\
\hline & & $\mathrm{T} 1$ & P0B2T1 & P0B2T1 & P0B2T1 \\
\hline & B0 & T0 & P1B0T0 & P1B0T0 & Р1B0T0 \\
\hline \multirow[t]{5}{*}{ P1 } & & $\mathrm{T} 1$ & P1B0T1 & P1B0T1 & P1B0T1 \\
\hline & B1 & T0 & P1B1T0 & P1B1T0 & P1B1T0 \\
\hline & & $\mathrm{T} 1$ & P1B1T1 & P1B1T1 & P1B1T1 \\
\hline & B2 & T0 & P1B2T0 & P1B2T0 & P1B2T0 \\
\hline & & $\mathrm{T} 1$ & P1B2T1 & P1B2T1 & P1B2T1 \\
\hline
\end{tabular}

Keterangan: $\mathrm{P} 0$ = Tanpa pupuk kimia (kontrol); P1 = Pupuk kimia; B0 = Tanpa agen khelator (kontrol); B1 = Inokulasi Agrobacterium sp. I ; B2 = Bahan organik (kompos); T0 = Tanpa tanaman (kontrol);

$\mathrm{T} 1$ = Rami (Boehmeria nivea).

\section{Persiapan Pupuk Kimia}

Penelitian ini menggunakan pupuk kimia, yaitu pupuk dasar NPK. Dosis B. nivea yang baik dalam pemberian pupuk NPK adalah 60 $\mathrm{kg} \mathrm{N}+20 \mathrm{~kg} \mathrm{P}_{2} \mathrm{O}_{5}+30 \mathrm{~kg} \mathrm{~K}_{2} \mathrm{O}$ perhektar (Purwati, 2010). Melakukan perhitungan berdasarkan kebutuhan pupuk NPK (15:15:15) pada tanaman. Perhitungan dilakukan agar mendapat pupuk tunggal $\mathrm{N}$, $\mathrm{P}$, dan $\mathrm{K}$ terlebih dahulu, kemudian menghitung dosis N, P, dan $\mathrm{K}$ pada masing-masing pupuk kimia (Urea, SP36, KCL). Perhitungan dosis pupuk NPK untuk $B$. nivea adalah Urea: $19,56 \mathrm{~g} /$ petak; SP36: $12,5 \mathrm{~g} /$ petak; $\mathrm{KCl}: 7,5 \mathrm{~g} /$ petak.

\section{Persiapan Agen Khelator Agrobacterium sp. I dan Bahan Organik (Kompos)}

Agrobacterium sp. I dikulturkan di media cair LB hingga diperoleh kepadatan $10^{10} \mathrm{CFU/}$ $\mathrm{mL}$ ( $\pm 72 \mathrm{jam}$ ). Pembuatan carrier (15 kg kompos; 7,5 kg dedak; $750 \mathrm{~mL}$ starter EM-4; dan $15 \mathrm{~L}$ air selama \pm 2 minggu), dikering angin, dan mensterilisasi dengan panci presto. Penambahan Agrobacterium sp. $\mathrm{I}_{3}$ pada pengkayaan carrier adalah sebanyak $600 \mathrm{~mL}$ inokulum untuk setiap 2 kg carrier. Sedangkan, Persiapan kompos dilakukan dengan menimbang pupuk kompos untuk B. nivea, yaitu $1,5 \mathrm{~kg} /$ petak.

\section{Persiapan Bibit Boehmeria nivea}

Persiapan bibit $B$. nivea terdiri dari perhitungan kebutuhan dan persiapan bibit. Perhitungan kebutuhan bibit mengacu pada jumlah perlakuan penanaman rami dan mendong beserta pengulangannya. Persiapan bibit terdiri dari pembuatan media pembibitan, proses pembibitan, dan perawatan bibit. Pembuatan media pembibitan dilakukan dengan mencampurkan tanah alfisol dan kompos (1:1). Memasukkan media pembibitan ke dalam polybag berdiameter $1,5 \mathrm{~cm}$. Pembibitan untuk $B$. nivea dengan metode stek batang.

\section{Uji Kadar Logam Cr Tanah}

Menimbang 2,5 g ctka berdiameter 0,5 $\mathrm{mm}$ ke dalam tabung digest dan menambahkan $5 \mathrm{~mL} \mathrm{HNO}_{3}$, dibiarkan satu malam. Memanaskan pada suhu $100{ }^{\circ} \mathrm{C}$ selama 1 jam 30 menit, mendinginkan, dan menambahkan $5 \mathrm{~mL} \mathrm{HNO}_{3}$ dan $1 \mathrm{~mL} \mathrm{HClO}_{4}$, kemudian memanaskan hingga $130{ }^{\circ} \mathrm{C}$ selama 1 jam, suhu ditingkatkan menjadi $150{ }^{\circ} \mathrm{C}$ selama 2 jam 30 menit (sampai uap kuning habis). Setelah uap kuning habis, suhu ditingkatkan menjadi 170 
${ }^{\circ} \mathrm{C}$ selama 1 jam, kemudian suhu ditingkatkan menjadi $200{ }^{\circ} \mathrm{C}$ selama 1 jam (hingga terbentuk uap putih).

Destruksi basah selesai dengan terbentuknya endapan putih atau sisa larutan jernih sekitar $1 \mathrm{~mL}$. Mendinginkan ekstrak dan mengencerkannya dengan air bebas ion menjadi $25 \mathrm{~mL}$, lalu menghomogenkan dan melanjutkan dengan pembacaan kandungan logam kromium dengan Atomic Absorption Spectrophotometer (AAS). Kandungan logam Cr (ppm) dihitung dengan rumus (Balai Penelitian Tanah, 2009):

\section{Kadar Cr=ppm kurvax10xfpxfk}

Keterangan:

ppm kurva $=$ kadar contoh didapat dari kurva regresi antara kadar deret standar dengan pembacaannya setelah dikurangi blanko.

$\mathrm{fp} \quad=$ faktor pengenceran.

$\mathrm{fk} \quad=$ faktor koreksi kadar air

$=100 /(100-\%$ kadar air $)$.

\section{Hasil dan Pembahasan}

Tanah sawah yang diteliti terletak di dekat pabrik tekstil dan sistem irigasi konvensional dari petani berperan dalam pemasokan logam $\mathrm{Cr}$ ke dalam tanah sawah. Kemampuan Boehmeria nivea diharapkan dapat menurunkan kadar logam Cr ke jaringan tumbuhan.

\section{Kemampuan Boehmeria nivea dalam Menurunkan Kadar Logam Cr Tanah}

Berdasarkan hasil analisis terhadap kadar logam $\mathrm{Cr}$ tanah, terjadi penurunan kadar setelah perlakuan. Kadar logam Cr tanah disajikan pada Gambar 1. Berdasarkan Gambar 1. Diketahui bahwa kadar logam $\mathrm{Cr}$ tanah awal adalah 2,36 ppm, hampir mendekati nilai ambang batas (NAB) logam $\mathrm{Cr}$ tanah yang diijinkan (2,5 ppm). Kadar logam $\mathrm{Cr}$ tanah pada kontrol (P0B0T0) sebesar 2,13 ppm. Kadar logam $\mathrm{Cr}$ tanah tertinggi pada perlakuan P1B0T0, yaitu 2,24 ppm. Sedangkan kadar logam $\mathrm{Cr}$ tanah terendah pada perlakuan P0B1T1 dan P0B2T1, yaitu 1,37 ppm.

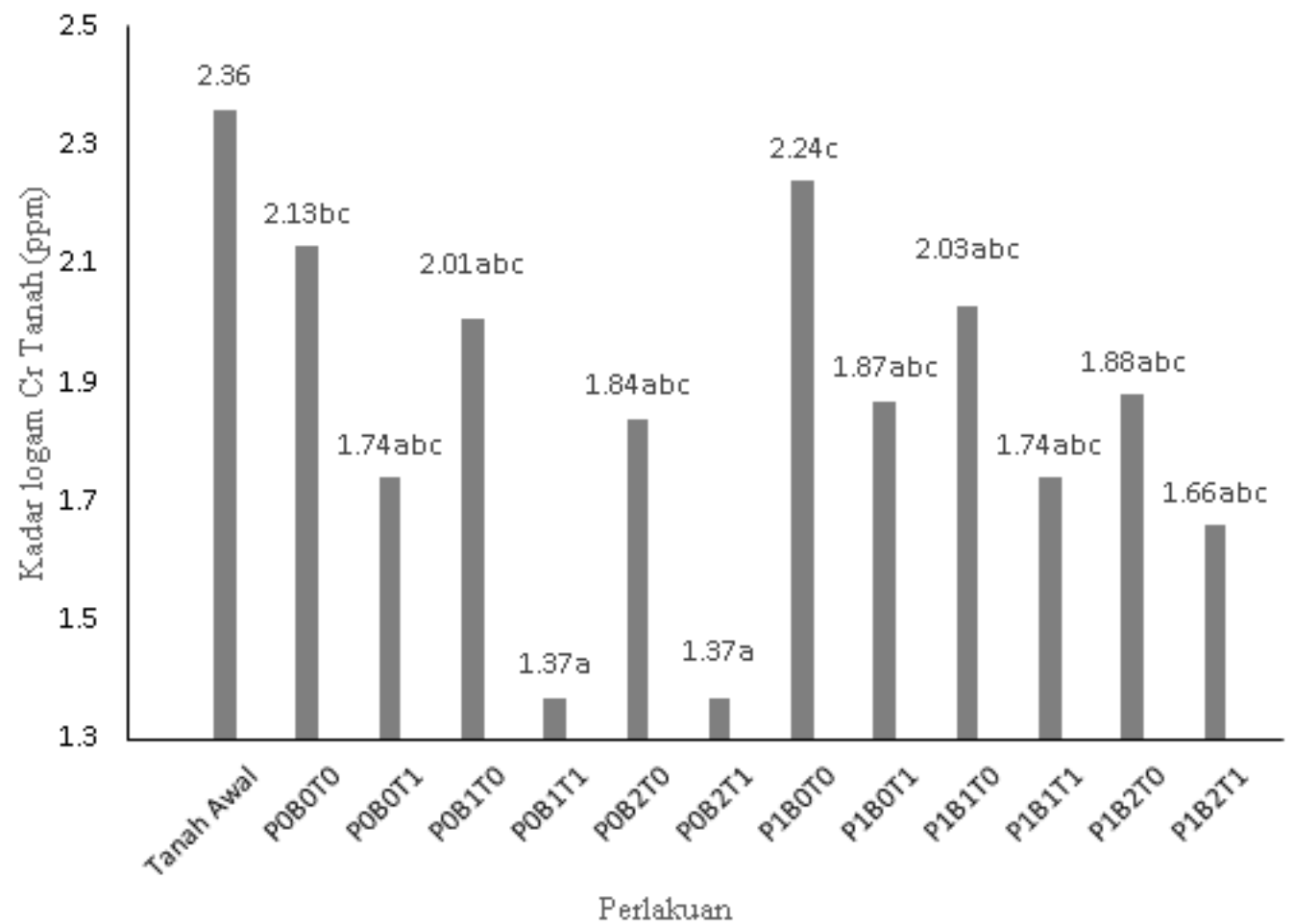

Gambar 1. Kadar Logam Cr Tanah 
Berdasarkan hasil analisis statistik diketahui bahwa terdapat dua perlakuan yang menunjukkan perbedaan nyata dibandingkan dengan kontrol, yaitu perlakuan P0B1T1 dan P0B2T1 dengan kadar logam $\mathrm{Cr}$ tanah sebesar 1,37 ppm atau 1,5 kali lebih rendah daripada kontrol. Mayoritas perlakuan menunjukkan penurunan kadar logam $\mathrm{Cr}$, kecuali perlakuan P1B0T0 dengan kadar logam $\mathrm{Cr}$ sebesar 2,24 ppm.

Berdasarkan hasil analisis terhadap penurunan kadar logam $\mathrm{Cr}$ tanah, terjadi penurunan kadar setelah perlakuan. Penurunan kadar logam $\mathrm{Cr}$ tanah (Gambar 2).

Berdasarkan Gambar 2. diketahui bahwa penurunan logam $\mathrm{Cr}$ tanah pada kontrol (P0B0T0) sebesar 10,18\%. Penurunan logam $\mathrm{Cr}$ tanah tertinggi pada perlakuan P0B1T1 dan
P0B2T1, yaitu sebesar 42,01 \%. Sedangkan, penurunan logam $\mathrm{Cr}$ tanah terendah pada perlakuan P1B0T0, yaitu sebesar 5,46 \%.

Berdasarkan pada besarnya penurunan kadar logam $\mathrm{Cr}$ tanah setelah perlakuan, diketahui bahwa perlakuan P0B1T1 dan P0B2T1 paling efektif dalam menurunkan kadar logam Cr tanah sebesar 1,37 ppm dengan tingkat penurunan kadar sebesar 42,01 \%. Perlakuan dengan tanpa pupuk kimia lebih baik daripada pemberian pupuk kimia. Ratarata kadar logam $\mathrm{Cr}$ tanah pada perlakuan tanpa pupuk kimia sebesar 1,74 ppm lebih rendah daripada pemberian pupuk kimia, yaitu 1,90 ppm. Pemberian pupuk kimia berpotensi dalam menambah kadar logam Cr dalam tanah (Setyorini et al., 2003).

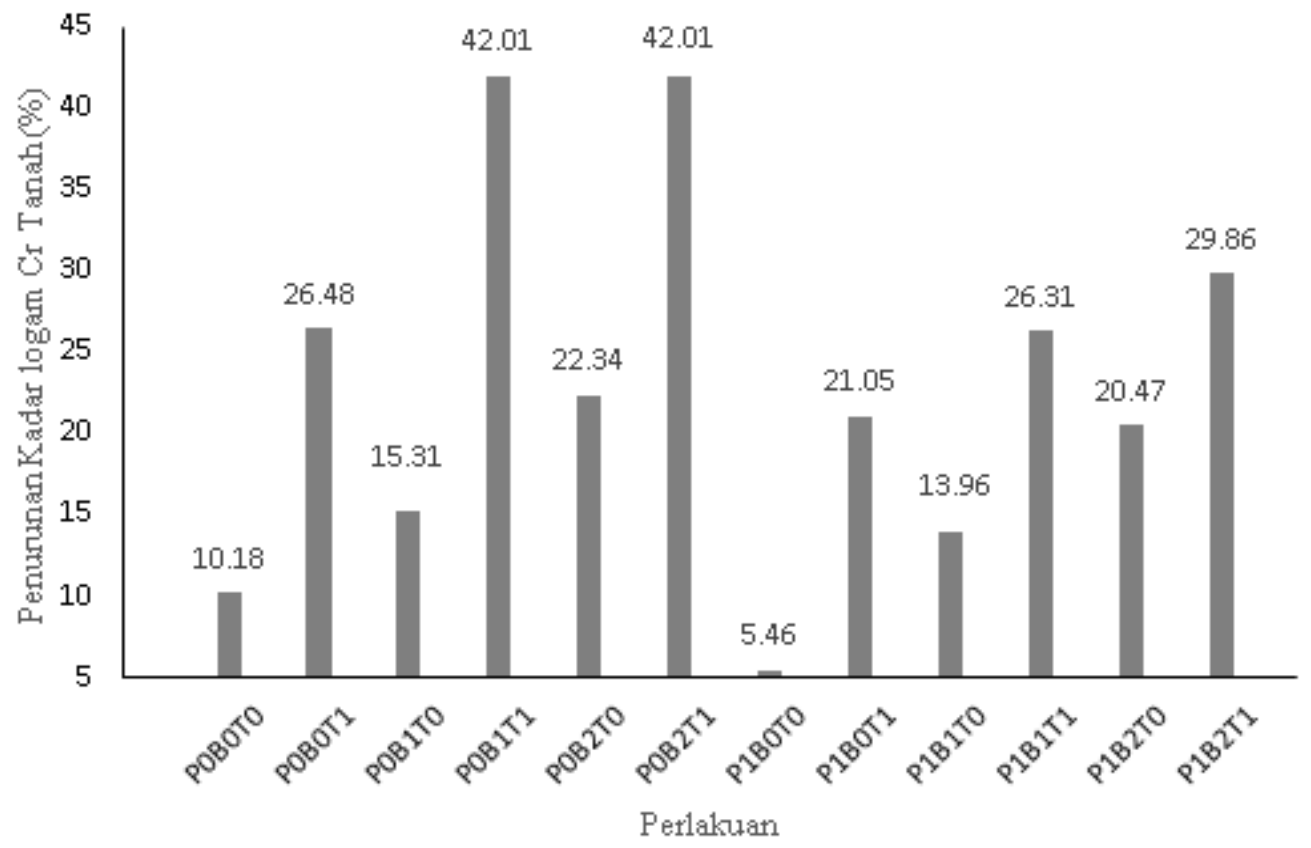

Gambar 2. Penurunan Kadar Logam Cr Tanah

Aplikasi Agrobacterium sp. $\mathrm{I}_{3}$ dan bahan organik berupa kompos tanpa pemberian pupuk kimia berperan penting dalam membantu menurunkan kadar logam $\mathrm{Cr}$ tanah. Agrobacterium sp. I $\mathrm{I}_{3}$ mampu meningkatkan penyerapan dan pengakumulasian logam $\mathrm{Cr}$ ke bagian akar dan tajuk $B$. nivea, sehingga dapat menurunkan kadar logam $\mathrm{Cr}$ pada tanah terkontaminasi (Rosariastuti et al., 2013). Kondisi tanah yang diberikan bahan organik dapat mempengaruhi aerasi tanah, peningkatan hara, dan peningkatan aktivitas mikroorganisme tanah yang dapat mendukung pertumbuhan $B$. nivea dalam membantu menurunkan kandungan logam Cr pada tanah (Sessitch et al., 2013). 
Penggunaan bahan organik (kompos) dari seresahan tumbuhan membantu menurunkan kadar logam pada tanah karena meningkatkan keefektifan fitoekstraksi, menambah kesuburan tanah, dan unsur hara (Singani dan Ahmadi, 2012; Tahmasbian dan Singani, 2014). Penambahan kompos dapat membantu Jatropha curcas L. dalam menurunkan kadar ion $\mathrm{Cr}(\mathrm{VI})$ pada tanah (Mangkoedihardjo et al., 2008).

Penambahan agen khelator berupa bahan organik yang dibantu oleh mikroba rizosfer tanah mengubah bioavailabilitas logam berat, sekresi khelator (asam organik, siderofor, enzim kromium reduktase), dan reaksi reduksi/ oksidasi mampu meningkatkan kemampuan tanaman dalam menyerap logam dan bertahan terhadap keracunan logam (Do Nascimento dan Xing, 2006; Khan et al., 2009; Kidd et al., 2009; Uroz et al., 2009; Wenzel, 2009; Rajkumar et al., 2010; Ma et al., 2011) sehingga penurunan kadar logam $\mathrm{Cr}$ di dalam tanah dengan $B$. nivea terjadi dengan baik.

\section{Solusi Kebijakan untuk Menjaga Sistem Pertanian Sehat Ramah Lingkungan}

Sistem pertanian sehat ramah lingkungan sangat penting dilakukan untuk menjaga stok pangan yang sehat dan aman untuk dikonsumsi. Kunci utama sistem pertanian sehat ramah lingkungan adalah dengan merawat lingkungan pertanian dari bahan pencemar. Manusia memiliki kepentingan dalam melestarikan lingkungan hidupnya karena dengan melestarikan lingkungan, manusia sudah berupaya untuk mempertahankan hidupnya (Keraf, 2002).

Sistem pertanian sehat ramah lingkungan mengandalkan pada berimbangnya siklus biogeokimia yang berlangsung di dalam sebuah ekosistem. Pada sistem pertanian sehat ramah lingkungan, penggunaan input kimiawi sangat dibatasi. Peran mikroorganisme tanah sangat penting untuk proses penguraian bahan-bahan organik yang bermanfaat untuk memperbaiki sifat fisika dan kimia dalam tanah, sehingga tercipta keamanan bahan pangan (Khan et al., 2007; Singh et al., 2011).
Prinsip pertanian sehat meliputi: 1). produksi bahan pangan berkualitas tinggi (bebas dari polutan anorganik beracun) dalam jumlah yang cukup; 2). upaya memperbaiki dan mendukung siklus biologis tanah dengan memaksimalkan fungsi mikroorganisme, flora, dan fauna tanah; 3). upaya mengelola dan meningkatkan kesuburan tanah; 4). minimalisasi kadar polutan dalam tanah; dan 5). memanfaatkan dan menghasilkan produk pertanian organik yang mudah dirombak dari sumber yang dapat didaur ulang (Suntoro, 2010).

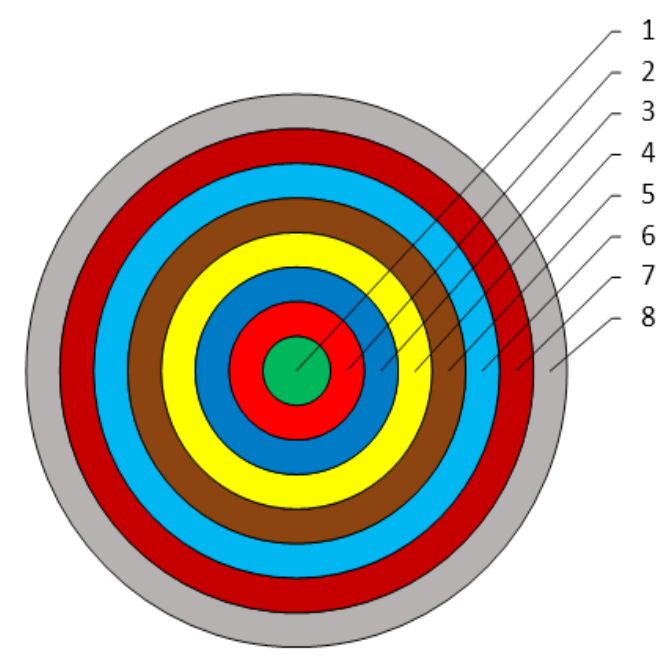

Gambar 3. Partisipasi Masyarakat Terhadap Pertanian Sehat Ramah Lingkungan

Keterangan:

1 = Petani

2 = Masyarakat

3 = Industriawan

4 = Akademisi

5 = Dinas Kesehatan

6 = Dinas Pertanian, Tanaman Pangan,

Perkebunan, dan Kehutanan

7 = Dinas Lingkungan Hidup

8 = Balai Penelitian dan Pengembangan

Provinsi Jawa Tengah

Kunci terciptanya pertanian yang sehat ramah lingkungan adalah tersedianya tanah yang sehat (subur dan produktif), yaitu tanah 
yang mampu menyokong pertumbuhan tanaman serta bebas dari berbagai bahan pencemar (Suntoro, 2010). Ketersediaan bahan organik di dalam tanah sangat penting dalam penyediaan unsur hara dan mempertahankan struktur tanah.

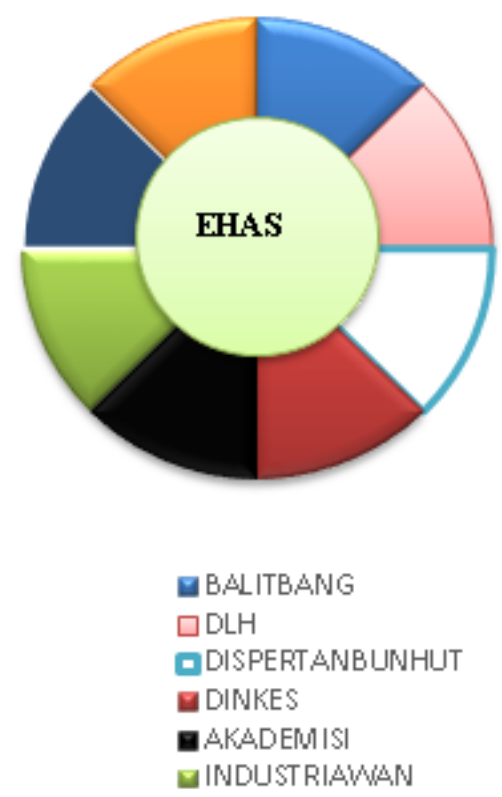

Gambar 4. Model Kolaborasi Pengelolaan Pertanian Sehat Ramah Lingkungan

Solusi kebijakan yang dapat digunakan untuk mendukung keberlanjutan proses fitoremediasi logam cr dengan boehmeria nivea demia terciptanya lahan pertanian yang memproduksi bahan pangan yang aman dan sehat adalah dengan konsep environment healt agriculture system (ehas). Solusi kebijakan disajikan pada tangga pastisipasi arnstein (arnstein, 1969).Tangga partisipasi arnstein mendeskripsikan bahwa tiga (3) tangga teratas yang ditunjukkan nomor 6 (dinas pertanian, tanaman pangan, perkebunan, dan kehutanan/ dispertanbunhut), 7 (dinas lingkungan hidup/ dlh), dan 8 (balai penelitian dan pengembangan provinsi jawa tengah/balitbang) merupakan penentu dalam fitoremediasi lahan pertanian tercemar logam berat, khususnya logam cr di kabupaten karanganyar. Fitoremediasi logam berat merupakan langkah awal untuk menuju sistem pertanian sehat ramah lingkungan. Modifikasi kolaborasi berdasarkan tangga partisipasi arnstein disajikan pada gambar 4 .
Berdasarkan fakta di lapangan menunjukkan bahwa kolaborasi dari semua pihak sangat penting dilakukan, dimulai dari proses fitoremediasi logam berat, khususnya logam $\mathrm{Cr}$, dilanjutkan dengan pengelolaan lahan pertanian yang berbasis lingkungan, kesadaran diri dari semua pihak terhadap kesehatan lingkungan sangat penting sebagai dasar pengelolaan. Koordinasi antarpengambil kebijakan penting untuk dilakukan.Penyuluhan kepada petani, masyarakat, dan industriawan oleh kalangan akademisi dan Pemerintah Kabupaten Karanganyar penting dilakukan demi menciptakan pertanian sehat ramah lingkungan. Solusi model kolaborasi bernama Environment Circle Colaboration (ECC). Model kolaborasi ini berbentuk lingkaran dengan pembagian yang sama, sehingga dalam pengelolaan pertanian sehat ramah lingkungan, semua pihak yang terlibat dalam ECC mempunyai peran yang sama (Arnstein, 1969).

\section{Simpulan}

Fitoremediasi logam kromium dengan rami (Boehmeria nivea) sangat efektif dalam menurunkan kadar logam kromium dalam tanah ditandai dengan efektivitas dua perlakuan, yaitu interaksi antara Agrobacterium sp. $\mathrm{I}_{3}$ dengan Boehmeria nivea (P0B1T1) dan interaksi antara bahan organik (kompos) dengan Boehmeria nivea (P0B2T1) diperoleh kadar logam $\mathrm{Cr}$ $1,37 \mathrm{ppm}$ dengan penurunan 42,01 \%. (2). Solusi kebijakan yang dihasilkan untuk menjaga keberlangsungan fitoremediasi demi terciptanya sistem pertanian sehat ramah lingkungan adalah Environment Health Agriculture System (EHAS).

\section{Ucapan Terima Kasih}

Kami mengucapkan terima kasih kepada Balai Penelitian dan Pengembangan (Balitbang) Provinsi Jawa Tengah, Lembaga Penelitian dan Pengabdian Masyarakat (LPPM) Universitas Sebelas Maret (UNS) Surakarta, dan tim penelitian. 


\section{DAFTAR REFERENSI}

Aji, A.C., Masykuri, M., Rosariastuti, R. (2017). Phytoremediation of rice field contaminated by chromium with mendong (Fimbristylis globulosa) to supporting sustainable agriculture. Proceeding. The $3^{\text {rd }}$ International Indonesian Forum for Asian Studies. Borderless Communities \& Nation with Borders Challenges of Globalisation. 1236-1247.

Arnstein. (1969). Social Participation Scale. Minneapolis, University of Minnesota Press.

Balai Penelitian Tanah. (2009). Analisis kimia Tanah, Tanaman, Air, dan Pupuk: Petunjuk Teknis Edisi 2. Balai Penelitian Tanah: Bogor.

Banks, M.K., Schwab, A.P., Henderson, C. (2006). Leaching and reduction of chromium in soil as affected by soil organic content and plants. Chemosphere. 62, 255-264.

Budiastuti, S. (2010). Ekologi Umum: Teori Dasar Pengelolaan Lingkungan. UNS Press: Surakarta.

Do Nascimento, C.W.A., Xing, B. (2006). Phytoextraction: A review on enhanced metal availability and plant accumulation. Sciencta Agricola. 63, 299-311.

Dogo, S., Razic, S., Manojlovic, D., Slavkovic, L. (2011). Analysis of the bioavailability of Cr (III) and Cr (VI) based on the determination of chromium in Mentha piperita by graphite furnace atomic absorption spectrometry. Journal of the Serbian Chemical Society. 76, 143-153.

Dong, J., Wu, F., Huang R., Zang, G. (2007). A chromium-tolerant plant growing in Cr contaminated land. International Journal of Phytoremediation. 9, 167-179.

Eastmond, D.A., MacGregor, J.T., Slesinki, R.S. (2008). Trivalent Chromium: Assessing the genotoxic risk of an essential trace element and widely used human and animal nutritional supplement. Critical Reviews in Toxicology. 28, 173-190.

Ghosh, M., Singh, S.P. (2005). A review on phytoremediation of heavy metals and utilization of its by products. Asian Journal on Energy and Environment. 3, 214-231.

Glick, B.R. (2010). Using soil bacteria to facilitate phytoremediation. Biotechnology Advances. 28, 367-374.

Han, F.X., Yi Su, Sridhar, M.B.B., Monts, D.L. (2004). Distribution, transformation and bioavailability of trivalent and hexavalent chromium in contaminated soil. Plant and Soil. 265, 243-252.

Han, R., Geller, J.T., Yang, L., Brodie, E.L., Chakraborty, R., Larsen, J.T., Beller, H.R. (2010). Physiological and transcriptional studies of $\mathrm{Cr}(\mathrm{VI})$ reduction under aerobic and denitrifying conditions by aquifer-derived Pseudomonad. Environmental Science and Technology. 44, 7491-7497.

Keraf, A.S. (2002). Etika Lingkungan. Kompas Media Nusantara: Jakarta..

Khan, M.S., Zaidi, A., Wani, P.A., Oves, M. (2009). Role of plant growth promoting rhizobacteria in the remediation of metal contaminated soils, Environmental Chemistry Letters. 7, 1-19.

Kidd, P., Barcelo, J., Bernal, M.P., Navari-Izzo, F., Poschenrieder, C., Shilev, S., Clemente, R., Monterroso, C. (2009). Trace element behaviour at the root-soil interface: Implications in phytoremediation. Environmental and Experimental Botany. 67, 243-259.

Ma, Y., Prasad, M.N.V., Rajkumar, M., Freitas, H. (2011). Plant growth promoting rhizobacteria and endophytes accelerate phytoremediation of metalliferous soils. Biotechnology Advances. 29, 248-258.

Mangkoedihardjo, S., Ratnawati, R., Alfianti, N. (2008). Phytoremediation of hexavalent chromium polluted soil using Pterocarpus indicus and Jatropha curcas L. World Applied Sciences Journal.

68-Fitoremediasi Logam Kromium... 
4, 338-342.

Owlad, M., Aroua, M.K., Daud, W.A.W., Baroutian, S. (2009). Removal of hexavalent chromiumcontaminated water and wastewater: A review. Water, Air, and Soil Pollution. 200, 59-77.

Peraturan Pemerintah Republik Indonesia Nomor 101 Tahun 2014 tentang Pengelolaan Limbah Bahan Berbahaya dan Beracun.

Pramono, A., Rosariastuti, R., Ngadiman, Prijambada, I.D. (2012). Peran rhizobakteria dalam fitoekstrasi logam berat kromium pada tanaman jagung. Ecolab. 6, 38-50.

Purwati, R.D. 2010. Strategi Pengembangan Rami (Boehmeria nivea Gaud.). Perspektif. 9, 106-118.

Rajkumar, M., Ae, N., Prasad, M.N.V., Freitas, H. (2010) Potential of siderophore-producing bacteria for improving heavy metal phytoextraction. Trends in Biotechnology. 28, 142-149.

Rosariastuti, R., Prijambada, I.D., Ngadiman, Prawidyarini, G.S., Putri, A.R. (2013). Isolation and identification of plant growth promoting and chromium uptake enhancing bacteria from soil contaminated by leather tanning industrial waste. Journal of Basic and Applied Sciences. 9, 243-251.

Sessitsch, A., Kuffner, M., Kidd, P., Vangronsveld, J., Wenzel, W.W., Fallmann, K., Puschenreiter, M. (2013). The role of plant-associated bacteria in the mobilization and phytoextraction of trace elements in contaminated soils. Soil Biology and Biochemistry. 60, 182-194.

Setyorini, D., Soeparto, Sulaeman. (2003). Kadar logam berat dalam pupuk. Prosiding Seminar Nasional Peningkatan Kualitas Lingkungan dan Produk Pertanian: Pertanian produktif ramah lingkungan mendukung ketahanan dan keamanan pangan. Pusat penelitian dan Pengembangan Tanah dan Agroklimat, badan Penelitian dan Pengembangan Pertanian, Jakarta. 219-229.

Shanker, A.K., Cervantes, C., Loza-Tavera, H., Avudainayagam, S. (2005). Chromium toxicity in plants. Environmental. International. 31, 739-753.

Singani, A.A.S., Ahmadi, P. (2012). Manure application and cannabis cultivation influence on speciation of lead and cadmium by selective sequential extraction. Soil Sediment Contam. 21, 305-321.

Singh, J.S., Kuffner, M., Singh, D.P. (2011). Efficient soil microorganism: A review dimension for sustainable agriculture and environmental development. Agriculture, Ecosystem, \& Environment. 140, 339-353.

Suntoro. (2010). Manajemen Sumber Daya Lahan Ramah Lingkungan. UNS Press: Surakarta.

Susarla, S., Medina, V.F., McCutcheon S.C. (2002). Phytoremediation: An ecological solution to organic chemical contamination. Ecological Engineering. 18, 647-658.

Tahmasbian, I., Singani, A.A.S. (2014). Chelate-assisted phytoextraction of cadmium from a mine soil by negatively charged sunflower. International Journal Environmental Science and Technology. $11,695-702$.

Undang Undang Republik Indonesia Nomor 32 Tahun 2009 Tentang Perlindungan dan Pengelolaan Lingkungan Hidup.

Uroz S., Calvaruso, C., Turpault, M.P., Frey-Klett, P. (2009). Mineral weathering by bacteria: ecology, actors and mechanisms. Trends in Microbiology. 17, 378-387.

Wenzel, W.W. (2009). Rhizosphere processes and management in plant-assisted bioremediation (phytoremediation) of soils. Plant and Soil. 321, 385-408. 